\title{
The G20 - OECD Contribution to a New Global Tax Governance ${ }^{1}$
}

\author{
M.F. Motala
}

Michael F. Motala - Researcher, G20 Research Group; Joseph-Armand Bombardier Doctoral Fellow, Social Science and Humanities Research Council of Canada; Frédéric Bastiat Fellow in Political Economy, Mercatus Center, George Mason University; Ethics of Artificial Intelligence Graduate Research Fellow, University of Toronto Center for Ethics; PhD Student, University of Toronto Department of Political Science; Munk School for Global Affairs and Public Policy, 1 Devonshire Place, Room 209 N, Toronto M5S 3K7 Ontario, Canada; E-mail: michael.motala@columbia.edu

\begin{abstract}
The 2012 transatlantic corporate tax scandals surrounding Amazon, Google and Starbucks exposed the scope and gravity of offshoring by digital multinationals, producing major dilemmas for the global governance of international fiscal law and policy. The Organisation for Economic Co-operation and Development [OECD, 2015] estimates corporate profit shifting erodes up to $\$ 240$ billion dollars from the global tax base every year. Extant literature has established links between corporate tax avoidance and accelerating domestic socio-economic inequality, the declining redistributive capacity of states, the malign impact on growth of gross domestic product (GDP), and the rise of antiglobalism in the form of populist discontent, providing unambiguous evidence that global tax competition causes social and economic harms. Responding to public outcry, world leaders at the Los Cabos summit in 2012 tasked the OECD with tackling national tax base erosion, and the Inclusive Framework for the Base Erosion and Profit Shifting (BEPS) initiative currently boasts 123 participating states, including 93\% of global GDP. Although taxation is at the heart of the social contract, this new global tax governance is both under-theorized and poorly understood in the mainstream political science literature. This study draws on the extra-disciplinary approach of law and economics to argue that while global tax cooperation under Group of 20(G20) - OECD auspices may be considered a success ex ante based on the record of first-order compliance, the ex post enforcement dimension of BEPS is both under-theorized and under-scrutinized empirically. This study contributes a novel meta-theory of the new global tax governance that accounts for the variables of time, institutional sphere of action and policy feedback loops embedded in the global fiscal policymaking process to stimulate further inquiry. It concludes with recommendations for global fiscal policy, further research on BEPS and G20 digital governance.
\end{abstract}

Key words: global tax governance; international taxation; fiscal relations; international political economy

For citation: Motala M.F. (2019) The G20 - OECD Contribution to a New Global Tax Governance. International Organisations Research Journal, vol. 14, no 2, pp. 52-79 (in Russian and English). DOI: 10.17323/1996-78452019-02-03.

\section{Introduction}

The 2012 transatlantic corporate tax scandals surrounding Amazon, Google and Starbucks exposed the scope and gravity of offshoring by digital multinationals, producing major dilemmas for global governance and international fiscal law and policy. When the British House of Commons Public Account Committee issued a report condemning the three companies for

${ }^{1}$ The editorial board received the article in January 2019. 
"immorally" using secret jurisdictions, royalties and complex corporate structures to avoid paying taxes, it ratcheted corporate taxation reform to the top of Britain's domestic, and then the international, political agendas [UK Public Accounts Committee, 2012]. The parliamentary committee excoriated executives from the three multinationals for their companies' respective failures to pay their "fair share" in British taxes. In 2012, for example, Starbucks, with a commanding 31\% share of the United Kingdom's coffee retailing market, reported annual sales of $£ 400$ million pounds. Yet the American company paid no British corporate tax because it had operated its British business at a loss throughout the preceding decade, allowing it to deduct losses against its earnings. Amazon, which had $£ 3.8$ billion in sales the same year, paid only $£ 1.8$ million in taxes since it was a British subsidiary of Amazon EU Sarl, headquartered in Luxembourg. Finally, although Google reported turnover of $£ 395$ million in 2012, it paid only $£ 6$ million in taxes to Her Majesty’s Treasury, with testifying company executives noting to the committee that the company "minimized tax within the letter of the law" and that "low tax areas or tax havens influenced where it located its group companies" [Public Accounts Committee, 2012, p. 10]. Responding to public outcry, world leaders convened at the Group of 20's (G20) Los Cabos summit in Mexico tasked the Organisation for Economic Co-operation and Development (OECD) with spearheading an initiative to tackle corporate profit shifting and tax base erosion. The OECD launched the Base Erosion and Profit Shifting (BEPS) initiative in 2012, consisting of a 15-element action plan addressing taxation issues in the digital economy.

Globally, the OECD estimates that corporate profit shifting depletes $\$ 100$ to $\$ 240$ billion from the global tax base every year [OECD, 2015] with some scholars going as far as to suggest worldwide annual revenue losses in excess of $\$ 280$ billion [Clausing, 2015, p. 2]. Although there is a paucity of comprehensive and reliable data, tax experts calculate the offshore banking industry shelters nearly $\$ 7.5$ trillion in assets [Kerzner, Chodikoff, 2016, p. 1]. According to one study, on average $40 \%$ of multinational corporate profits are shifted to tax havens, avoiding taxes where the underlying activities take place [Tørsløv, Wier, Zucman, 2018]. Indeed, as confirmed in Securities and Exchange Commission (SEC) 10-K filings from March 2016, Apple held $92.8 \%$ of its $\$ 215.7$ billion cash reserves offshore; Microsoft offshored $93.9 \%$ of its $\$ 102.6$ billion in reserves; and Google had $58.7 \%$ of its $\$ 73.1$ billion in reserves held off United States soil [Srnicek, 2017, p. 41].

The foregoing corporate scandals are paradigmatic of the broader threat posed by global tax competition for national liberal democracy. On the supply side of global tax law and policy, national governments competitively underbid each other for corporate tax revenues in a phenomenon known as the race to the bottom [Piketty, Saez, Stantcheva, 2011; Piketty, Saez, 2012; Piketty, 2013]. Since 1980, the average global statutory corporate tax rate has declined from $38 \%$ to just $24 \%$ [Alepin et al., 2002, p. 451; Otis, 2017]. On the demand side of policy, tax-paying multinational enterprises engage in sophisticated tax planning to artificially shift their profits away from the locus of economic activity to the lowest-tax jurisdiction internationally. Only a few firms benefit from global tax competition since the largest $0.001 \%$ of all firms earn a third of corporate profits, with profit shifting isolated to the top bracket [Wier, Reynolds, 2018, p. 1]. As D.H. Robertson long predicted, in the fiscal realm contemporary multinational corporations have become "islands of conscious power in an ocean of unconscious cooperation" [Hymer, 1970; Motala, 2018b].

In effect, since worldwide tax deregulation in the 1980s, a select group of transnational enterprises commanding disproportionate market power have eviscerated the state's capacity to administer corporate taxation. Since taxation lies at the heart of the social contract, economic globalization has undercut the state's traditional redistributive capacity threatening an acceleration of national income inequalities [Baldwin, 2016; Milanovic, 2016]. As tax scholar R. Avi-Yonah explains, the combination of globalization and tax competition will "lead to a fiscal crisis for 
countries that wish to continue to provide social insurance to their citizens at the same time that demographic factors and the increased income inequality, job insecurity, and income volatility that result from globalization render such social insurance more necessary" [cited in Kuttner, 2016, p. 223]. In short, the fate of the liberal democratic welfare state hangs in the balance.

There is an urgent and largely unaddressed institutional gap in the extant international fiscal regime, and global policymakers are tasked with institutionalizing a new global tax governance to address the problems of global tax competition and the race to the bottom for corporate tax receipts [Motala, 2018b]. At the Antalya summit in November 2015, the leaders of the G20 and OECD endorsed the OECD's BEPS package. As of 2019, 123 countries representing 93\% of global gross domestic product (GDP) are participating in the BEPS Inclusive Framework, and further implementation is underway globally [OECD, 2018e, p. 109]. At the Buenos Aires summit in November 2018, world leaders committed to continuing to work "for a globally fair, sustainable, and modern tax system based, in particular on tax treaties and transfer pricing rules, and welcome international cooperation to advance pro-growth policies," adding that the implementation of BEPS was "essential" [G20, 2018b]. Yet it remains an open question whether the BEPS initiative will prove to be a successful case of fiscal regime creation and institutional performance.

Global tax governance and the G20 - OECD's institutional performance here remains relatively unexamined in the political science literature [Dietsch, Rixen, 2016]. So too has there been scant interdisciplinary cross-fertilization [Ibid.]. Indeed, as the prominent 20th century public economist A. C. Pigou remarked, "up to this point I have taken no account of international relations... when this assumption is removed, several new and large problems arise [cited in Mendoza, Tesar, 1998, p. 226]. Moreover, comparison with the extra-disciplinary approaches of law and economics leaves political scientists with an intractable puzzle, encouraging further inquiry into this emergent issue area.

On the one hand, international tax cooperation has been lauded by some as a critical test case of global governance in the aftermath of the 2008 global financial crisis [Eccleston, 2012, p. 2]. The G20's performance is widely praised, according to R. Eccleston, because leaders were "keen to highlight their diplomatic achievements" [Ibid.]. According to the G20 Research Group's analysis, out of the 75 tax-related commitments made by world leaders since 2008, the five assessed yielded an overall compliance of $87 \%$ [Motala, 2018a, pp. 114-5]. Following the Hamburg summit in 2018, the G20 boasted 100\% compliance with BEPS-related action items, potential evidence of an upward trend [Ibid.]. In the words of the OECD, "the BEPS package of measures represents the first substantial renovation of the international tax rules in almost a century" [OECD, 2018e, p. 3]. Appraising global tax governance ex ante through the top-down analysis of agenda-setting, negotiation and compliance, the empirical record since 2008 suggests BEPS is a case study par excellence of successful global economic cooperation.

Yet looking ex post, the burgeoning extra-disciplinary literature offers a sobering assessment of the trajectory of global tax governance. "[D]espite the growing resolve among world leaders to address the problem," Eccleston elaborates, "the reality is that reaching and enforcing international tax agreements is notoriously difficult" [Eccleston, 2012, p. 2]. R. Woodward, moreover, predicts patterns of "mock compliance" with the proposed BEPS initiative [Woodward, 2016] in a seminal interdisciplinary volume on global tax governance [Dietsch, Rixen, 2016]. In part due to the fundamental distributive contest underlying international taxation, legal scholar I. Grinberg [2015] similarly predicts the initiative will result in mock compliance or outright failure [Motala, 2016a; 2016b; 2016c]. Arguing BEPS is unlikely to succeed in the context of tax competition, political scientists P. Dietsch and T. Rixen propose a new global governance institution to oversee global fiscal law. In the legal literature leading scholars concur in their assessment of BEPS [Graetz, 2015; 2016; Grinberg, 2015]. 
The consequences of hitherto ineffective fiscal cooperation are also borne out in the economics literature, fortifying an ex post argument about the failure of global tax governance emphasizing the monitoring and enforcement dimensions of BEPS. In recent years, economist T. Piketty has identified a significant positive correlation between decreased rates of capital taxation and increases in domestic social inequality [Piketty, Saez, 2004; 2012; Piketty, Saez, Stantcheva, 2011; Piketty, 2013]. Yet, as Dietsch and Rixen point out, Piketty's research falls short of examining the distributive implications of decreased tax rates [2016, p. 9, n. 9]. Fortunately, research by global inequality scholar B. Milanovic has addressed this gap. Based on a robust study of global household income data, Milanovic concludes a fortiori that the growing inequality identified by Piketty is evidence that the "redistributive function of the modern developed state has either become weaker or remained more or less the same as in the 1980s" [2016, p. 106].

Since the 1980s, the proportion of economic activity contributed by multinational enterprises (MNEs) has grown substantially [Guvenen et al., 2017, p. 2]. In 2012, for example, economists calculate that the global value added of U.S. MNEs was \$4.66 trillion, "making them equivalent to the fourth-largest economy in the world, tied with Japan and trailing only the United States, the European Union, and China" [Ibid.]. U.S. MNEs reported $\$ 800$ billion in worldwide income in 2012, taxed at an average of 6.6\% [Clausing, 2015, p. 27]. Scholars estimate the United States government alone loses up to $\$ 111$ billion annually [Ibid.] Analyzing firm-level data, Guvenen et al. recently found corporate profit shifting reduced U.S. GDP [2017, p. 1]. More recently, J. Bruner, D.G. Raisser and K.J. Ruhl estimated the GDP loss at $1.5 \%$ [2018, p. 2]. The 2012 transatlantic tax scandal surrounding Amazon, Google and Starbucks brought the scale of corporate tax avoidance to the public fore, underscoring the limitations of the existing OECD fiscal paradigm. As the eminent international taxation scholar M. Graetz argues, "the dominant analytical framework used by policymakers to evaluate international tax policy is archaic" [2015, p. vii]. To paraphrase Graetz, our 21st century global fiscal policy is governed by inadequate 20th century rules [Doud, Graetz, 2013; Graetz, 2015; 2016].

Is global tax cooperation under G20 - OECD auspices since 2012 a success, as some global summitry scholars would argue ex ante in view of the record of first-order compliance, or is the initiative destined for failure, as predicted by other political scientists, economists and legal scholars arguing ex post in light of the empirical evidence and intuitions about asymmetric cooperation under conditions of global tax competition? Put simply, what are the determinants of global fiscal cooperation under BEPS? And what are the implications, if any, of gaps in our understanding for a credible assessment of the new global tax governance?

\section{Thesis}

To answer these questions, this study adopts an interdisciplinary and synthetic methodological approach that integrates the empirical and theoretical insights of the extant political economy, law and economics literatures. The main object of this inquiry is to systematically map the empirical and theoretical discourse to propose a generative meta-theoretical framework for further study. This paper argues that the enforcement dimension of global taxation is under-theorized and poorly understood in the mainstream political science literature, with two significant consequences for the theory and praxis of global economic governance. To address the gap in the literature this paper makes two contributions to the global taxation policy debate. First, it offers tentative conclusions about the state of global tax governance based on a synthesis of the interdisciplinary empirical record. Second, it maps the landscape of existing global tax governance theory to help generate further research on the topic. Drawing on the extra-disciplinary approaches of law and economics, this paper argues scholars must consider the roles of time, 
institutional sphere of action and policy feedback loops in their analysis of political agenda setting, negotiation/standard setting, implementation, monitoring and enforcement in the global fiscal policy process.

Existing literature has established the link between corporate tax avoidance and increasing domestic socio-economic inequality, the declining redistributive capacity of states and the malign impact on growth, estimated at a $1.5 \%$ annual GDP loss, providing clear evidence that global tax competition causes social and economic harm [Baldwin, Okubo, 2009; Baldwin, 2016; Milanovic, 2016; Piketty, Saez, Stantcheva, 2011; Piketty, Saez, 2012; Piketty, 2013]. Moreover, the competitive sovereignty-preserving nature of global taxation predisposes any global governance initiative to mock compliance and failure, undercutting sanguine predictions about the prospects for the G20 - OECD BEPS initiative. Two causal conclusions follow: to date, G20 - OECD tax governance has failed because it has not sufficiently accounted for domestic legalization and enforcement dimensions of the fiscal policy process, and as a result of this governance failure the resultant global tax competition will continue to have deleterious social and economic consequences in the form of accelerating domestic social inequality and anti-globalism in the form of populist discontent [Kirton, 2019]. In short, the available evidence warrants more intensive international cooperation and coordinated legal enforcement, through courts at the domestic level and through sanctions against non-compliant regimes internationally.

Such a holistic consideration of the available evidence and theory suggests the contemporary global tax regime is a market failure due to high transaction costs, information asymmetries, anti-competitive collusion and free riding. Rather than being destined for success, the conditions of international anarchy and asymmetric cooperation pose serious global collective action problems for the implementation of BEPS. Thus, although the BEPS process may be considered a success ex ante in terms of first-order compliance, as it stands there is insufficient evidence to evaluate the substantive second-order success of the global policy initiative given lack of progress and data on BEPS enforcement. To address these challenges, this study concludes with recommendations for enhancing the theory and praxis of global tax governance and suggests further avenues for research.

\section{Background on Global Tax Competition and Governance Failure}

The state's sovereign tax prerogative traces to the Treaty of Westphalia agreed in 1648, which established the basis for the state's coercive powers of taxation in Articles LXV and LXVIII [Treaty of Westphalia, 1648]. Similarly, Article I, Section 8 of the Constitution of the United States of America affords U.S. Congress the power "to lay and collect taxes, duties, imposts and excises." The Westphalian paradigm of absolute fiscal sovereignty remained unchallenged from the mid-17th to the early 20 th century.

The rapid expansion of international trade during the interwar years exposed the "[n]atural tension between sovereignty and international tax policy" [Kerzner, Chodikoff, 2016, p. 43]. As Eccleston points out, fundamental governance issues arise when taxing the profits of transnational business [2012, p. 18]. When crossing national borders, goods risked being taxed twice on the same underlying activity - a phenomenon known as double taxation - which thereby perverted incentives for global production and trade. ${ }^{2}$ The International Chamber of Commerce (ICC) lobbied the nascent League of Nations to find a solution to the problem of

${ }^{2}$ In 1918, foreseeing the potential economic inefficiencies threatened by double taxation, the United States Congress legislated a unilateral tax credit for foreign source income, enabling American companies to deduct taxes paid abroad from their United States' corporate tax liabilities [Rixen, 2011, p. 9]. 
double taxation. The League tasked scholars E. Seligman, Sir J. Stamp, G.W.J. Bruins and L. Einaudi with designing an intergovernmental effort, and in 1923 they produced a set of proposals [Motala, 2018b, p. 367]. The 1923 report of the League's Economic and Financial Commission promulgated the fiscal norms of residence and source in global tax law and regulation [Economic and Financial Commission, 1923]. Nearly a century later, their report remains the basis of extant global fiscal law.

To address the problem of competing tax claims arising from international trade, the group of economists proposed a doctrine of economic allegiance to govern global fiscal relations: put simply, the architects of the global taxation system assumed transnational entities would be fully taxed somewhere. ${ }^{3}$ They proposed four factors to determine a taxpayer's economic allegiance, viz. where wealth was acquired, located, was the subject of enforceable rights and consumed [Li, Cockfield, Wilkie, 2014, p. 23]. In practice, the doctrine of economic allegiance was codified in over 3,500 bilateral double taxation agreements (DTAs) that govern the distribution of international tax revenues. DTAs rely on three instruments to prevent double taxation: they exempt foreign-sourced income from domestic tax collection; they permit deductions for taxes paid abroad; and they afford domestic tax credits for foreign tax liabilities [Keen, 1992]. As D.S. Kerzner and D.W. Chodikoff explain, "one of the primary goals of international tax policy is to relieve double taxation through a 'mediation' of the claims of residence and source so that income is taxed only once" [2016, p. 40].

Originally responsible for the administration of the Marshall Plan in Europe, following the ratification of the Convention on the Organisation for Economic Co-operation and Development [OECD, 1960] the OECD was transformed into a forum for economic policy [Motala, 2018b, p. 397]. During the 1960s, the under-taxation of corporate profits displaced double taxation as the leading issue in global fiscal law because of the growth of MNEs [Rixen, 2011, pp. 1-2] Unlike conventional domestic firms, MNES posed unique challenges because they "engage in investment and have ownership of or control of activities in more than one country" [Motala, 2018b, p. 376]. Seen from the global perspective, an MNEs is a transnational corporate structure that operates as a singular entity. However, from the perspective of national law, each branch and subsidiary operates as a discrete individual entity. Thus, individual units of the larger firm can trade with other branches and subsidiaries for above or below fair market value, creating opportunities for profit shifting and tax base erosion. Moreover, the sheer complexity of the extant DTA network affords multinational corporations with ample opportunities to identify loopholes and offshore their profits to avoid corporate tax using efficient legal planning.

In 1963, the OECD's Committee on Fiscal Affairs drafted a Model Tax Convention on Income and Capital to serve as a template for DTAs with a view to harmonizing global tax practice [OECD, 2017]. Article 9 of the Model Convention enshrined the arm's length principle to tackle international tax avoidance. ${ }^{4}$ In addition to promulgating model tax treaties, the OECD sup-

\footnotetext{
${ }^{3}$ Messrs. Bruins, Einaudi, Seligman, and Sir J. Stamp elaborated on the theory of economic allegiance as follows: "A part of the total sum paid according to the ability of a person ought to reach the competing authorities according to his economic interest under each authority. The ideal solution is that the individual's whole faculty should be taxed, but that it should be taxed only once, and that liability should be divided among the tax districts according to his relative interests in each [Economic and Financial Commission, 1923, p. 20; Li, Cockfield, Wilkie, 2014, p. 23].

${ }^{4}$ For greater clarity, Article 9 of the OECD Model Tax Convention on Income and Capital (2017) stipulates that where "an enterprise of a Contracting State participates directly or indirectly in the management, control or capital of an enterprise of the other contracting state" or "the same persons participate directly or indirectly in the management, control or capital of an enterprise of a Contracting State and an enterprise of the other Contracting state," and in either case "conditions are made or imposed between two enterprises in their contractual or financial relations which differ from those which would be made between independent enterprises, then any profits which would, but for those conditions, have accrued to one of the enterprises, but,
} 
plies members with technical commentary on implementation that is used by bureaucrats and courts to interpret tax law [Cockfield, 2006, p. 142]. Nevertheless, the complexity of the DTA network combined with worldwide corporate tax deregulation and the spate of global mergers and acquisitions in the 1980s produced a race to the bottom fiscal policy competition, driving the average worldwide corporate tax rate down six points by the end of the decade [Edwards, Keen 1996, p. 114]. MNEs began using sophisticated tax planning methods involving transfer pricing, intra-group loans and treaty shopping to lower their tax liabilities. Global tax havens gave MNEs the tools to do so legally.

What are the basic mechanisms of global tax base erosion and corporate profit shifting? On the supply side of global tax law and policy, given the conditions of international anarchy states are faced with an asymmetric prisoner's dilemma with "well-known predictions [for] global cooperation" [Dietsch, Rixen, 2016, p. 326; Kemmerling, Seils, 2009, p. 758]. The lack of international hierarchy promotes a distributional regulatory competition among states competing for tax revenues [Kemmerling, 2011, p. 6]. Global tax competition is thus the "inevitable result of the decentralized nature of international taxation" [Dagan, 2018, p. 12]. The abovecited decline in average global corporate taxation rates since the 1980s provides sufficient empirical support for these claims. On the demand side of fiscal law and policy, MNEs employ efficient tax planning techniques to reduce their aggregate tax liabilities.

To understand the mechanisms of global tax governance, scholars must eschew the abstract idealizations of the market that dominate the economics literature. Instead, only when markets are "embedded within the context of a welfare state, which engages in both marketcomplementing and redistributive policies, that capitalism as a whole can claim to be just" [Heath, 2014, p. 10]. ${ }^{5}$ Taxation is thus best understood "as a vehicle for allocating the costs of government in an equitable and efficient manner" [Dagan, 2018, p. 15]. Accordingly, scholars can employ a standard of Pareto optimality to empirically assess whether tax competition is harmful or beneficial for society [Keen, Wildasin, 2004]. More research is urgently needed to continue assessing the impact of tax base erosion and corporate profit shifting. Adjudicating the existing evidence on taxation, redistribution and income inequality using the Paretian normative standard - which dictates that some must be better off, and none are worse off, because of a given profit-maximizing strategy - it is clear that corporate tax avoidance benefits the few at the expense of the many, with deleterious social and economic consequences.

Under conditions of international anarchy states have incentives to introduce preferential tax regimes, as they have no impact on existing sources of tax revenue from domestic sources [Kemmerling, Seils, 2009, p. 759]. Similarly, poor countries are incentivized to cut tax rates and offer special tax treatment to expand their tax base [Ibid.]. J.D. Wilson [1986] and G.R. Zodrow and P. Mieszkowski [1986] conducted the first equilibrium analyses of tax competition proving these results. Assuming international anarchy, multiple small states and perfect capital mobility, theory predicts declining rates of taxation characteristic of the race to the bottom [Kemmerling, Selis, 2009, p. 758]. As predicted by the asymmetric prisoner's dilemma, non-cooperation is the only possible outcome since states benefit asymmetrically from the distributional contest for taxation revenues [Dietsch, Rixen, 2016; Kemmerling, Selis, 2009; Wilson, 1986; Zodrow, Mieszkowski, 1986]. Modern tax competition has yielded a classical global market failure characterized by high transaction costs, free riding, information asymmetries and profitable anticompetitive collusion [Dagan, 2018, p. 216].

by reason of those conditions, have not so accrued, may be included in the profits of that enterprise and taxed accordingly" [OECD, 2017]. The arm's length principle, in essence, clarifies the standard of what constitutes a fair market price between two unrelated transacting parties in transaction, serving as a bedrock of the OECD's BEPS rule-making surrounding transfer pricing.

${ }^{5}$ Please note that parenthetical text is omitted from this quotation. 
In the 1990s, the OECD began investigating the impact of tax havens and offshoring on global economic growth and development [Kerzner, Chodikoff, 2016, p. 53]. At a meeting in Turku, Finland in 1997, OECD members first discussed the challenges posed by cross-border e-commerce [Cockfield, 2006, p. 140]. In 1998, at the OECD ministerial meeting in Ottawa, Canada, the Committee for Fiscal Affairs endorsed new principles of reform as part of the Ottawa Taxation Framework [Ibid.]. In 1998, the OECD released five "broad taxation principles which should apply to electronic commerce" [OECD, 1998, p. 4]. First, that "taxation should seek to be neutral and equitable," meaning "taxpayers in similar situations carrying out similar transactions should be subject to similar levels of taxation" [Ibid.]. As T. Dagan elaborates, neutrality is the core objective of international tax policy because it seeks to avoid "arbitrary differences in tax rates," helping to "reduce distortions of decisions about what to consume and how to produce it" [2018, p. 16]. Second, the OECD promulgated the principle of efficiency to reduce the costs of tax administration [1998, p. 4]. Third, it prescribed certainty and simplicity, meaning taxpayers should be able to understand and anticipate their tax liabilities based on the existing rules.

Fourth, the OECD promulgated the combined principles of effectiveness and fairness, meaning "taxation should produce the right amount of tax at the right time" such that corporations do not avoid duly owed taxes [Ibid.] Thus, a notion of distributive justice, which "requires normative deliberation" is at the core of global tax policy [Dagan, 2018, p. 17]. Fifth, and finally, the OECD prescribed the principle of flexibility: "the systems of taxation should be flexible and dynamic to ensure that they keep pace with technological and commercial developments [1998, p. 4]. In 2002, the OECD turned its attention to the role of information exchange among national tax authorities, releasing the model Agreement on Exchange of Information in Tax Matters [2002]. Given the lack of concerted national action on tax avoidance, the OECD has assumed a central stewardship role, promulgating guiding principles and tax rules to address tax policy concerns [Ibid., p. 139]. The organization also fosters the development of transnational tax policy networks and works closely with other intergovernmental organizations [Sharman, 2012, p. 23]. Given the OECD's role in facilitating deliberation, building intergovernmental consensus and prescribing norms and non-binding treaties, scholars argue the international organization is effectively a quasi-world tax organization [Cockfield, 2006].

\section{G20 - OECD Contribution to the New Global Tax Governance}

The G20 summit was formed in the wake of the financial crisis in 2008 as a result of a threefold impetus: first, it was clear existing institutions were incapable of managing the crisis; second, the balance of power had shifted from the advanced market economies to the east; and third, political leadership would be required at the highest levels [Cooper, Thakur, 2013; Cooper, Pouliot, 2015; Hajnal, 2014, p. 16; Kirton, 2013a; 2013b; Larionova, Rakhmangulov, Shelepov, 2015a; Larionova et al., 2015b]. Since the club's inception, the OECD has participated in every summit [Ibid., p. 58]. The G20 first addressed the OECD's work on international taxation at its summit in Washington in 2008. In the final summit communiqué, world leaders encouraged tax authorities to draw on the work of the OECD in the area of tax information exchange, further declaring that the "lack of transparency and... failure to exchange tax information should be vigorously addressed." At the London summit in 2009, leaders declared: "[w]e stand ready to take agreed action against those jurisdictions which do not meet international standards in relation to tax transparency" [Ibid.]. In Cannes for the 2011 summit, the G20 further emphasized its stance against tax havens, committing to "protect our public finances from the risks posed by tax havens and non-cooperative jurisdictions" [Ibid.]. In 2012, in the 
wake of the transatlantic corporate tax scandals implicating Amazon, Starbucks and Google, G20 finance ministers tasked the OECD with launching an initiative to address tax base erosion and corporate profit shifting. At the landmark Los Cabos summit in 2012, world leaders explicitly addressed the "need to prevent base erosion and profit shifting" and indicated that they "will follow with attention the ongoing work on the OECD in this area" [Ibid.]. According to J. Kirton and J. Kulik's [2012a; 2012b] analysis, Los Cabos was a "summit of significant success."

In June 2013, the OECD delivered its 15-point action plan to the United States government. The following September, world leaders endorsed the OECD's Base Erosion and Profit Shifting (BEPS) action plan. At St. Petersburg in 2013, the G20 committed to a new automatic exchange of information standard (AEOI) and reaffirmed its previous commitments. In 2014 at Brisbane, the G20 welcomed progress on BEPS. In October 2015, the OECD presented the outputs of the BEPS project to G20 finance ministers. The G20 leaders then reaffirmed their commitments at Antalya in 2015 and Hangzhou in 2016. At the Hamburg summit in 2017, the G20 committed to adopting defensive measures against non-cooperative jurisdictions. Finally, in 2018 at the summit in Buenos Aires, leaders committed to "secure sustainable tax systems," strongly endorsed the OECD's progress with BEPS implementation and reiterated the concert's willingness to resort to "defensive measures" against "jurisdictions that have not satisfactorily implemented the tax transparency standards" [G20, 2018b].

Since 2008, the G20 has made 75 commitments on international taxation, which represents $3 \%$ of its 2,397 commitments overall [Motala, 2018a]. Of the 75 commitments made since 2008, the five corresponding with the BEPS project were assessed by the G20 Research Group at the University of Toronto, yielding an overall compliance score of $87 \%$ and rising [Ibid.]. The G20 achieved 68\% compliance with its first assessed commitment at St. Petersburg, where the group committed to change the rules to address tax avoidance and aggressive corporate tax planning. The G20's commitment to introduce an automatic exchange of information (AEOI) standard at Antalya in 2015 received a compliance score of $90 \%$. The G20 was $83 \%$ compliant with its commitment to further support BEPS made at Hangzhou in 2016. Finally, following the Hamburg summit in 2017, the G20 received 100\% interim compliance with BEPS action items.

According to the OECD, "the BEPS package of measures represents the first substantial renovation of the international tax rules in almost a century" [OECD, 2018e, p. 3]. In addition to being composed of fifteen specific action items to address taxation in the digital economy, BEPS is concerned with three overriding policy objectives. ${ }^{6}$ First, the BEPS project seeks to "reinforce the coherence of corporate income tax rules at the international level" [Ibid., p. 109]. Second, it seeks to "realign taxation with the substance of economic activities" [Ibid.]. Third, the G20 - OECD initiative seems to "improve transparency" [Ibid.]. The BEPS project entered the implementation phase in 2015. As of the time of writing, 113 countries or jurisdictions totalling $93 \%$ of global GDP have joined the Inclusive Framework on BEPS [Ibid., p. 3].

${ }^{6}$ The fifteen BEPS action items are as follows: Action 1: Address the Challenges of the Digital Economy; Action 2: Neutralize the Effects of Hybrid Mismatch Arrangements; Action 3: Strengthen CFC Rules; Action 4: Limit Base Erosion Via Interest Deductions and Other Financial Arrangements; Action 5: Counter Harmful Tax Practices More Effectively, Taking Into Account Transparency and Substance; Action 6: Prevent Treaty Abuse; Article 7: Prevent Artificial Avoidance of PE Status; Actions 8-10: Assure That Transfer Price Outcomes Are in Line With Value Creation (Intangibles; Risks and Capital; Other High-Risk Transactions); Action 11: Establish Methodologies to Collect and Analyze Data on BEPS and the Actions to Address It; Action 12: Require Taxpayers to Disclose Their Aggressive Tax Planning Arrangements; Action 13: Re-Examine Transfer Pricing Documentation; Action 14: Make Dispute Resolution Mechanisms More Effective; and Action 15: Develop a Multilateral Instrument. See Motala [2018b]. 
Following the negotiation of a multilateral instrument (MI) as part of Action 15 of BEPS, 67 countries signed a multilateral treaty enabling the swift implementation of BEPS [Ibid.].

In 2018, the OECD updated the G20 on global progress implementing BEPS' four minimum standards. The first standard is contained in Action 5 of BEPS and consists of conducting a peer review of preferential tax regimes and a commitment to transparency through spontaneous exchange of judicial rulings [OECD, 2018a]. The objective of the first standard is to "realign the location of taxable profits with the location of the underlying economic activity and value creation" [OECD, 2018e, p. 111]. The OECD reported good progress with the first standard citing the example of the EU, which issued a directive mandating the automatic exchange in 2015 [Ibid., p. 112]. The second standard is contained in Action 6 of BEPS and is comprised of measures to prevent tax treaty abuse through the "granting of treaty benefits in inappropriate circumstances" [OECD, 2018d]. The minimum standard under Action 6 involves the implementation of anti-abuse provisions in tax treaties [OECD, 2018e, p. 114]. The OECD reported widespread implementation of the anti-abuse measures through bilateral renegotiation and the MI, which binds 78 jurisdictions in total, covering 1,200 DTAs [Ibid., pp. 115-6].

The third minimum standard is contained in BEPS Action 13 on country-by-country $(\mathrm{CbC})$ reporting. The OECD developed a template for MNEs to report their income for members, and facilitated implementation using model legislation and competent authority agreements to facilitate intergovernmental information exchange [OECD, 2018c]. Since the standard was promulgated, the OECD reports "jurisdictions have made great efforts to establish the necessary legal and administrative frameworks," noting the "global landscape for CbC reporting by MNE groups is still evolving" [Ibid.]. In 2018, the OECD reported 95\% of MNEs are expected to be affected by $\mathrm{CbC}$ reporting requirements [OECD, 2018e, p. 115]. The fourth minimum standard is contained in Action 14, and calls for a dispute resolution mechanism [OECD, 2018b]. Perhaps the most ambitious of all, it is concerned with implementing a framework that supersedes the current ineffective mutual agreement procedure (MAP).

Beyond the four minimum standards, the OECD reported on the domestic implication of other action items concerning interest deductibility (Action 4), neutralizing hybrid mismatches (Action 2), best practices guidelines for controlled foreign companies (Action 3 ) and mandatory disclosure rules (Action 12) [OECD, 2018e, p. 116]. To this end, the EU and U.S. implemented anti-avoidance measures to address hybrid instruments and entities [Ibid., p. 117]. In addition, the U.S. introduced rules limiting interest deductibility in excess of $30 \%$, with several countries including Argentina, India, Korea, South Africa, Norway, Japan, Malaysia and Turkey in the process of considering or having implemented similar rules [Ibid.]. Despite progress with BEPS, however, the OECD has previously cited concerns with missing micro-data on MNE tax practices [OECD, 2015, pp. 30-1]. In the OECD's 2018 report to the G20, the organization called for "a better understanding of how the BEPS recommendations are implemented in practice" and noted that a "[g]reater focus on implementation and tax administration should therefore be mutually beneficial to governments and business" [Ibid., p. 3].

To date, G20 - OECD tax governance has failed because it has not sufficiently accounted for the domestic legalization and enforcement dimensions of the fiscal policy process, and as a result of this governance failure global tax competition will continue to have deleterious social and economic consequences manifested in accelerating domestic social inequality and antiglobalism in the form of populist discontent [Kirton, 2019]. In short, the available evidence warrants more intensive international cooperation and coordinated legal enforcement through courts at the domestic level and through sanctions against non-compliant regimes internationally. 


\section{The New Global Tax Governance Meta-Theory}

This paper contributes a meta-theoretical model of the new global tax governance that distills the insights of structural neorealism, liberal institutionalism, social constructivism, the model of systemic hub governance and law and economics in order to stimulate further research. Dietsch and Rixen first proposed a five-stage model comprised of political agenda setting, negotiation/standard setting, implementation, monitoring and enforcement [2016, p. 333]. The first two stages, diplomacy and agenda-setting and negotiation and standard setting, from $t_{0}$ to $t_{1}$, occur ex ante (Fig. 1). The last three stages, viz. implementation, monitoring and enforcement, occur in the period from $t_{1}$ to $t_{2}$, and are considered to be ex post (Fig. 1).

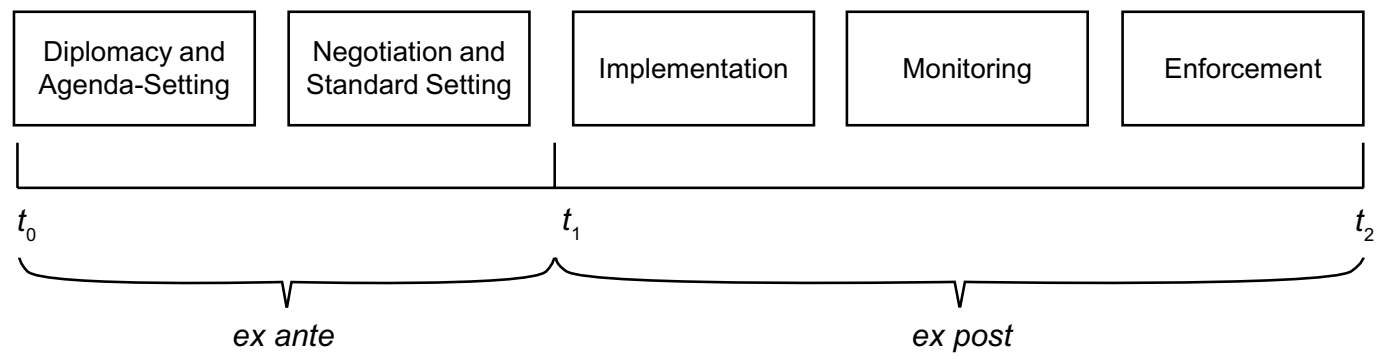

Fig. 1. General Model of Global Fiscal Governance Process

Source: author's simulacrum of the explanatory diagram provided in Dietsch and Rixen [2016, p. 333].

Yet, global fiscal policymaking does not operate in a vacuum. Rather, the five-step governance model takes place in various institutional spheres of action: plurilateral summits, state diplomacy, national executives, international institutions, national regulators, transnational networks, epistemic communities, MNEs, courts, legislative bodies and elsewhere. Building on their model, this section argues that scholars must also consider the institutional sphere of action in which each stage of the fiscal policy process takes place, while accounting for the interests of relevant actors and the dynamic policy equilibria at each stage in the global fiscal policy process.

In addition, scholars must consider the underlying policy feedback loops generated by the interaction of states and markets, namely through legal enforcement of fiscal law and MNE interest group politics. To understand why global tax policy forms a feedback loop, consider the comparative economic governance structures for global taxation and financial regulation (Fig. 2) [Motala, 2018b, p. 403]. As depicted in the figure below, at each stage in Dietsch and Rixen's [2016] model governance process, the substance of fiscal policy is subject to the influence of different political actors within a particular sphere of action. Negotiation and standard setting, for example, take place in international organizations, while it is the task of national regulators to implement global fiscal policy and civil society's responsibility to monitor compliance. Emphasizing the enforcement dimension of the new global tax governance focuses critical attention on the interaction between state and market. MNEs are subject to fiscal compliance and enforcement measures, and via interest group politics they can reciprocally determine the content of global tax law and policy, initiating a feedback policy loop from the domestic to state level of policy [Latulippe, 2016]. It is worth noting not all spheres of global economic governance are the same, in part explaining the comparative success of BEPS and global financial regulation under Basel I and II. Indeed, as highlighted in Fig. 2 with hashed lines, institutional arrangements matter. Compared to national tax administrations, central banks like the 
Bank of England and Federal Reserve enjoy greater political independence, and thus insulation from interest group politics, than traditional national tax administrations.

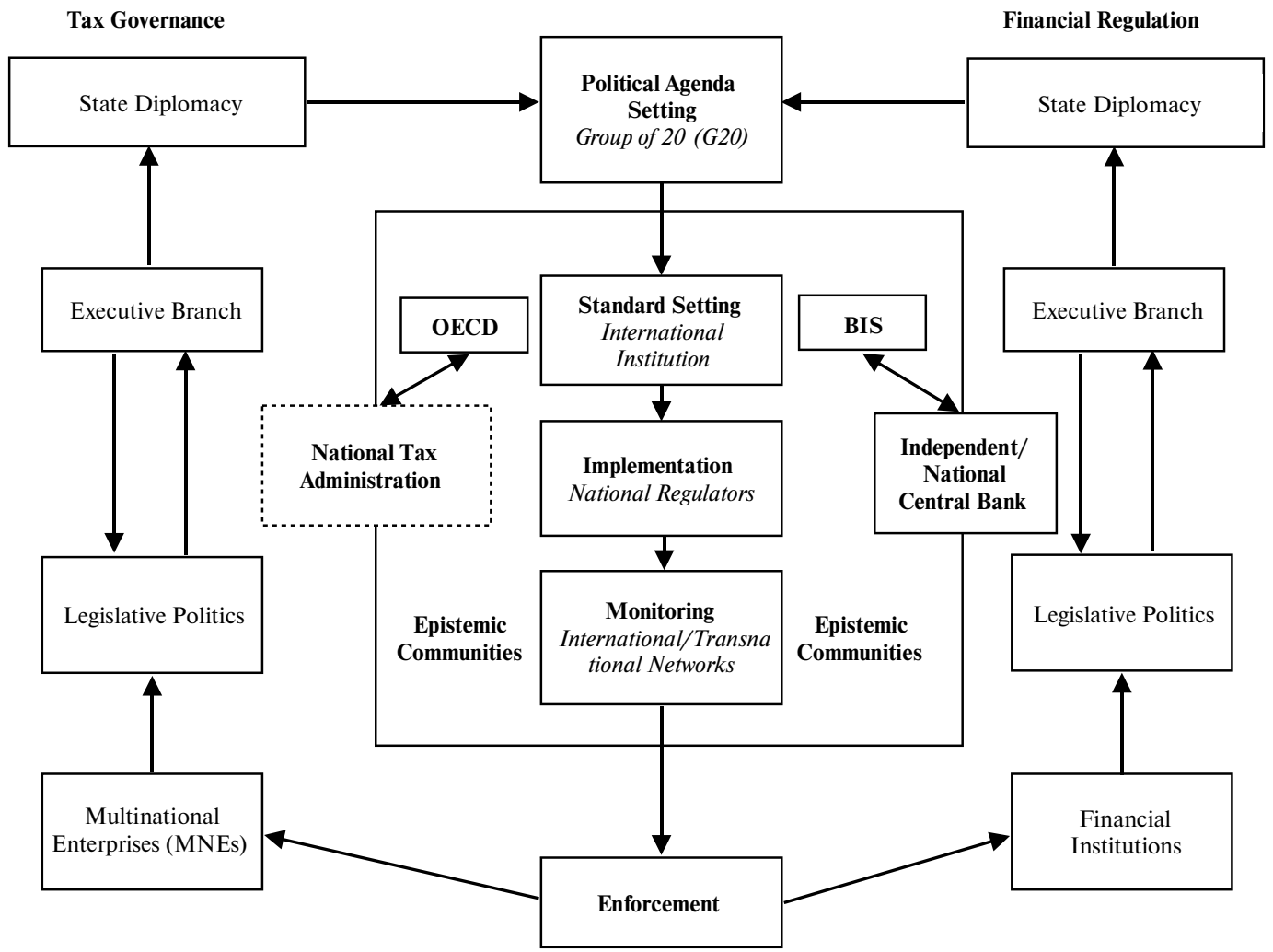

Fig. 2. Comparative Global Economic Policy Feedback Loops

Source: [Motala, 2018b, p. 403].

Table 1. Theoretical Landscape of the New Global Tax Governance

\begin{tabular}{|c|c|c|c|}
\hline & Stage of Process & Institutional Sphere of Action & Relevant Schools of Thought \\
\hline \multirow[t]{2}{*}{ Ex Ante } & $\begin{array}{l}\text { Diplomacy and Agenda- } \\
\text { Setting }\end{array}$ & G20; OECD & $\begin{array}{l}\text { Structural Realism } \\
\text { Liberal Institutionalism } \\
\text { Social Constructivism } \\
\text { Model of Systemic Hub Governance }\end{array}$ \\
\hline & $\begin{array}{l}\text { Negotiation and Standard } \\
\text { Setting }\end{array}$ & $\begin{array}{l}\text { G20; OECD; Epistemic } \\
\text { Communities }\end{array}$ & $\begin{array}{l}\text { Liberal Institutionalism } \\
\text { Social Constructivism } \\
\text { Model of Systemic Hub Governance }\end{array}$ \\
\hline \multirow[t]{3}{*}{ Ex Post } & Implementation & $\begin{array}{l}\text { OECD; State (Executive; Legislative; } \\
\text { Bureaucratic); MNEs }\end{array}$ & $\begin{array}{l}\text { Liberal Institutionalism } \\
\text { Social Constructivism } \\
\text { Model of Systemic Hub Governance }\end{array}$ \\
\hline & Monitoring & $\begin{array}{l}\text { OECD; State (Bureaucratic); } \\
\text { Civil Society; Non-Governmental } \\
\text { Organizations; Epistemic } \\
\text { Communities }\end{array}$ & $\begin{array}{l}\text { Social Constructivism } \\
\text { Model of Systemic Hub Governance }\end{array}$ \\
\hline & Enforcement & State (Bureaucratic, Courts); MNEs & Law and Economics of Globalization (5) \\
\hline
\end{tabular}

Source: compiled by the author. 
As argued and shown in Table 1, taken together, structural realism and liberal institutionalism furnish the best insights on global fiscal relations ex ante through their focus on power/ realpolitik and institutions, respectively. Constructivism equips global governance scholars with tools for understanding the underlying social processes driving global tax governance ex ante and ex post. Similarly, the model of systemic hub governance offers insights on global governance ex ante, though its comparative strength is that it is also capable of helping reconcile the ex post dimension of the governance model by measuring first-order compliance. Notably, as further elaborated, only law and economics is suited to analyzing the ex post enforcement stage, extending the analysis from first-order to second-order compliance - a much needed shift in analytic emphasis.

\section{Ex Ante}

\section{Structural Realism}

The first two schools of thought, structural realism and liberal institutionalism, furnish scholars with a superficial understanding of the complexity of global tax governance. However, their contrasting zero-sum and joint-gain logics described below provide a useful starting point for framing the high-level strategic imperatives underlying G20 - OECD BEPS diplomatic process. The first school of thought is structural neorealism, which assumes that international cooperation is a zero-sum game [Carr, 1974; Waltz, 1979]. Realism clarifies the role of rational self-interest and the material nature underlying the distributional contest found on the supply and demand sides of global tax competition. Structural realism supplies insights on the diplomacy and agenda-setting dynamic at the G20 and OECD with its focus on great power rivalry and hegemony. On the supply side of law and policy, realism predicts that leading powers will seek to maintain their privileged position in the international system by constructing favourable institutional arrangements [Simmons, 2001]. A surface level analysis might suggest similar dynamics in the BEPS process. The fact that the U.S. and UK spearheaded the BEPS process following the 2012 transatlantic tax scandal is ostensibly similar to coordination between the Federal Reserve and Bank of England during the Basel process. Yet a closer examination of the facts shows the structural realist analogy is limited. While the U.S. and UK enjoy a concentration of financial power in capital markets, financial services firms are by nature physical and territorially bound, and thus subject to effective enforcement. In this context, hegemonic financial power plays a diminished causal role. As J. Kirton concludes, realism is broadly relevant, but the causal connections are "seldom straightforward" [2013b, p. 29]. Global governance scholars must also consider the role of international institutions in negotiating and setting fiscal standards.

\section{Liberal Institutionalism}

The second school of thought is liberal institutionalism which is premised on a joint-gains logic of international cooperation [Keohane, 1977; 1984; Krasner, 1976; Ruggie, 1982]. Liberal institutionalism focuses on transaction costs, fostering transparency and trust and minimizing cheating [Kirton, 2013a, p. 30]. Unlike structural realism's reverence for self-interest, liberal institutionalism is predicated on the concept of Pareto efficient gains from cooperation. It does not take the BEPS process to be a zero-sum distributional contest. Rather, the BEPS process involves a diffusion from soft law standards promulgated by the OECD to hard law in the member states participating in the Inclusive Framework. The liberal institutionalist literature on legalization adds useful detail to the analysis of institutional performance. K.W. Abbott et 
al. define legalization as a "set of characteristics that institutions may (or may not) possess," understood along the three dimensions of obligation, precision and delegation [2000, p. 401]. Judged against this rubric, given the strong record of first-order compliance with BEPS and broad regulatory implementation in treaties and statutes, liberal institutionalists would argue that the G20 and OECD have successfully constructed a fiscal regime characterized by hard legalization [Ibid., p. 402]. Yet, as elaborated below, legalization scholars must move beyond an analysis of first-order compliance and reconcile their theory with the realities of corporate tax law and economics.

\section{Ex Ante and Ex Post}

\section{Social Constructivism}

The third school of thought is social constructivism [Adler, 1997; Reus-Smit, 2001; Wendt, 1998]. E. Adler [1997] and A. Wendt [1998] tell us the world is composed of social facts which reflect our intersubjective understandings of the world. The political world is irreducibly social in nature for constructivists, and knowledge is the source of power. Constructivists thus account for the role of identity, norm creation and dissemination, communicative action and the social causes of international cooperation and discord. Social constructivism expands the analysis to include the transnational epistemic community centred at the OECD which is responsible for creating and promulgating tax principles, rules and fiscal norms [Haas, 1992; Schmidt, 2008]. In light of L. Latulippe's [2016] recent study that highlighted the extent of corporate influence in Canadian fiscal policymaking, constructivism equips global governance scholars with the tools necessary for understanding the social processes of corporate interest group politics. However, due to its irreducibly social approach the theory is under-inclusive of materialist factors in its analysis and should be considered as part of a synthetic or mid-range theory together with structural realism, liberal institutionalism and the following approaches.

\section{Model of Systemic Hub Governance}

The fourth school of thought is the model of systemic hub governance. Taking the concert equality model [Kirton 1989; 1993; 1999; 2000; 2013a; 2013b] as its starting point, the model of systemic hub governance is a compact and coherent causal model that "accounts for the G20's creation, evolution, and performance as the consequences, as well as the forces that combined to cause this particular pattern of behaviour" [Kirton, 2013a, p. 36]. How effective are global governance institutions [Kirton, 2015, p. 241; Larionova, Rakhmangulov, Shelepov, 2015a; Larionova et al., 2015b]? Kirton [2015] makes four arguments about international institutional effectiveness. First, it is conceptualized in terms of first-order implementation and assessed empirically using textual data [Ibid., p. 241]. Second, assessments must look not only to conformity with public commitments but also to implementation outcomes [Ibid., p. 242]. Third, assessments require better measurements of consensus, commitments, compliance and the extent to which institutions accomplish their mandates [Ibid.]. Fourth, and finally, better multi-stakeholder mechanisms are required to assess compliance [Ibid.].

In addition to its account of institutional effectiveness, the six dimensions of global governance identified by the model of systemic hub governance transcend the ex ante and ex post aspects of the global tax governance model articulated above, and the model is the best available theory in the literature. Taking stock of domestic political management [Kirton, 2013a, p. 36], deliberation [Ibid., p. 37], direction setting [Ibid.], decision-making [Ibid.], delivery [Ibid., p. 38] and development of global governance [Ibid., p. 39] furnishes global governance 
scholars with a useful heuristic for assessing the institutional performance of the G20 - OECD BEPS initiative. Furthermore, the model clarifies the key causes of institutional performance in this case study. Similar to the genesis of the plurilateral club, the transatlantic tax scandal in 2012 was an acute shock that awakened G20 leaders to their collective vulnerability to tax base erosion and corporate profit shifting [Kirton, 2013a, p. 42]. The scandal further highlighted the multilateral organizational failure of extant institutional arrangements governing tax [Ibid., p. 44]. While the model of systemic hub governance provides the most rigorous and coherent explanation of global institutional cooperation and the causes of G20 performance, it is underinclusive. To avoid a compositional fallacy, global governance scholars must take a holistic view of the governance process depicted in the model above. The model of systemic hub governance must further account for patterns of legal enforcement at the domestic level in its assessment of BEPS and global fiscal relations more generally.

\section{Expost}

\section{Law and Economics}

The fifth school of thought draws insights from the cognate fields of international taxation, law and economics and globalization studies. Looking ex post at the empirical record of global tax avoidance and its impact on the state's redistributive capacity [Piketty, 2013; Piketty, Saez, Stantcheva, 2011; Piketty, Saez, 2012; Milanovic, 2016], there is compelling evidence of the malign impact of global tax competition and the need for greater cooperation and enforcement. International tax scholars are accordingly much less sanguine than political scientists who assess global tax governance strictly ex ante. K.A. Clausing, for example, argues that "there are many reasons to suspect that profit shifting problems are not over," citing the non-binding nature of BEPS standards and uneven implementation [2015, p. 22]. I. Grinberg [2015] predicts that BEPS will result in mock compliance and outright failure.

Dagan argues that although multilateral efforts appear cooperative on the surface, "these initiatives have been undercut by collective action problems and tainted by the biases and selfinterests of those initiating and leading the efforts" [2018, pp. 214-5]. At its core, the "decentralized competitive structure of the international tax regime is based on a network of states engaged in strategic interaction with each other," and the "multiplicity and fragmentation of the different national tax regimes, the variance in tax mechanisms, and the diversity in definitions supplied by the various systems combine to provide tax planners with necessary flexibility to minimize their tax liability" [Dagan, 2018, p. 215]. Indeed, as J. Li [2017] demonstrates, with its focus on double non-taxation, the BEPS initiative is failing to keep pace with the prospect of triple non-taxation. Rather than being destined for success, the conditions of international anarchy and asymmetric cooperation pose serious global collective action problems for the implementation of BEPS. Thus, although the BEPS process may be considered a success ex ante in terms of first-order compliance, as it stands there is insufficient evidence to evaluate the substantive second-order success of the global policy initiative given lack of progress and data on BEPS enforcement.

Thinking about global tax governance under G20 - OECD auspices as a multi-stage process that occurs in different institutional spheres of action enables one to map out the relevant insights generated by the five schools of thought in further research. Such a holistic consideration of the available evidence and theory suggests the contemporary global tax regime is a market failure due to high transaction costs, information asymmetries, anti-competitive collusion and free riding. To address these challenges, this study concludes with recommendations for enhancing the theory and praxis of global tax governance and suggests further avenues for research. 


\section{Prospects and Recommendations}

This study has argued that the enforcement dimension of global taxation is under-theorized and poorly understood in the extant political science literature, with two significant consequences for the theory and praxis of global economic governance. This section makes four recommendations concerning a proposed framework for future research, tax transparency and enforcement.

\section{A Framework for Future Research: The New Global Tax Governance Meta-Theory}

Global fiscal relations are under-theorized and under-examined in the political science literature. To better understand the new global tax governance, this paper argues that scholars should adopt the proposed problem-solving meta-theory which "takes the world as it finds it, with the prevailing power relationships and institutions in which they are organized, as the given framework for action" [Cox, 1986, p. 208]. To address the gap in the literature, future research should assess BEPS against the five stages of the global fiscal policy process in terms of the dimensions of time, institutional sphere of action and embedded policy feedback loops.

\section{Tax Transparency}

Global governance scholars also require more robust domestic- and company-level data to assess patterns of second-order compliance-qua-enforcement at the domestic and transnational level. Indeed, as the OECD found, current efforts are challenged by the problem of missing microdata [2015, pp. 30-1]. Although the OECD has released tax law jurisprudence, there are gaps in our understanding of firm-level implementation [OECD, 2018e]. Within the scope of the existing BEPS Inclusive Framework, future research should assess the underlying data on $\mathrm{MNE} \mathrm{CbC}$ reporting, spontaneous information exchange standards and sanctions levied against tax havens to assess implementation and enforcement. Should G20 - OECD efforts to increase global tax transparency under the $\mathrm{CbC}$ and spontaneous exchange standards fail, world leaders should consider creating a global registry of corporate securities to give tax administrators a holistic picture of MNE finances [Zucman, 2015]. The G20 - OECD must strive to improve tax transparency to combat the information asymmetries underlying corporate tax avoidance and profit shifting.

\section{Enforcement}

To put it succinctly, global policymakers must enact "concrete sanctions proportional to the costs imposed by uncooperative tax havens" [Zucman, 2015, p. 75]. Arguing BEPS is unlikely to succeed in the context of tax competition, political scientists Dietsch and Rixen propose a new global governance institution to oversee global fiscal law. In light of the asymmetric prisoner's dilemma at the heart of global tax competition, the authors argue we need "an institution that supports a cooperative solution" with "strong monitoring and enforcement mechanisms" [2016, p. 326]. States need to move from bilateralism, namely the practice of managing the global fiscal pie through over 3,500 DTAs, to true multilateralism [Ibid.]. It is still an open question whether the BEPS multilateral instrument will be evenly implemented. Moreover, the authors argue that global taxation requires "a legalized dispute-settlement procedure very similar to that of the World Trade Organization (WTO)" [Ibid.]. Although the OECD has been lauded as a "quasiWorld Tax Organization" by some [Cockfield, 2006], to be truly effective, such an organization would require binding and coercive powers to combat harmful tax competition. 
Moreover, working within the existing international economic regime, scholars and policymakers could revisit the WTO's binding enforcement regime. While international trade regulation is concerned with the anti-competitive harms of governments protecting local industry from foreign competition, international fiscal regulation is concerned with states privileging foreign-source income at the expense of a level playing field for domestic industry. The contemporary subsidies and countervailing measures $(\mathrm{SCM})$ regime excludes double taxation from the WTO's remit on the basis of Paragraph (e) in the Illustrative List of Export Subsidies in the annex of the SCM agreement. While Footnote 59 currently exempts consideration of double non-taxation from its remit, a revised SCM could usefully expand the WTO's jurisdiction into taxation matters, improving overall enforcement patterns against uncooperative and anti-competitive regimes without having to establish an entirely new international organization.

\section{G20 Digital Governance}

The issues of global tax base erosion and MNE profit shifting are intimately connected with the growth of e-commerce and the transnational digital economy, and the G20's failure to make taxation a part of its digitalization agenda represents a missed opportunity. Digitalization first appeared on the G20 agenda at the Washington summit in 2008, when world leaders identified e-commerce as a potential tool for managing the financial crisis [Kirton, Warren, 2018, p. 26]. Following Hangzhou in 2016, the G20's digitalization agenda entered a new and more expansive phase, with world leaders endorsing more intensive collaborative efforts to measure the digital economy's effects [Ibid.]. In August 2018, the G20 issued a ministerial declaration reaffirming the group's commitment to participate in the development of infrastructure, international standards and efforts to address gaps along key dimensions [G20, 2018a; 2018b]. To date, J. Kirton and B. Warren [2018] argue that the G20's digitalization efforts have been an increasing success. By linking the issues of taxation and digitalization, the $\mathrm{G} 20$ is poised to facilitate greater synergies and institutional effectiveness in global economic governance.

\section{Conclusion}

Although taxation is at the heart of the social contract, political science has only recently turned its attention to the new global tax governance [Motala, 2018b, p. 366]. This study has argued that while global tax cooperation under G20 - OECD auspices may be considered a success ex ante based on the record of first-order compliance, the five-stage theoretical framework elaborated here demonstrates that the ex post enforcement dimension of BEPS is both under-theorized and under-scrutinized empirically. A holistic consideration of the available evidence and theory suggests that the contemporary global tax regime is a classical market failure, and that global tax governance is predisposed to significant collective action problems due to asymmetric cooperation and the underlying distributional contest at the heart of global tax competition. Judging the available empirical evidence on enforcement against a Paretian normative standard, there is a clear need for greater international cooperation, enforcement, data-collection and analysis. While BEPS is to be lauded as a step in the right direction, it is clear that double non-taxation will not be the final frontier of sovereign tax imagination. 


\section{References}

Abbott K.W., Keohane R.O., Moravcsik A., Slaughter A., Snidal D. (2000) The Concept of Legalization. International Organization, vol. 54, no 3, pp. 401-19.

Adler E. (1997) Seizing the Middle Ground: Constructivism in World Politics. European Journal of International Relations, vol. 3, no 3, pp. 319-63.

Alepin B., Otis L. (2018) The Global Tax War May Already Be Under Way. The Globe and Mail, 1 January. Available at: https://www.theglobeandmail.com/report-on-business/rob-commentary/the-global-tax-warmay-already-be-under-way/article37470600/ (accessed 20 December 2018).

Baldwin R. (2016) The Great Convergence: Information Technology and the New Globalization. Cambridge: The Belknap Press of Harvard University.

Baldwin R., Okubo T. (2009) Tax Reform, Relocation, and Heterogenous Firms. The Scandinavian Journal of Economics, vol. 111, no 4, pp. 741-64.

Bruner J., Raisser D.G., Ruhl K J. (2018) Multinational Profit Shifting and Measures Throughout Economic Accounts. NBER Working Paper No 24915, National Bureau of Economic Research. Available at: https:// www.nber.org/papers/w24915 (accessed 28 December 2018).

Carr E.H. (1964) The Twenty Years Crisis: 1919-1939. London: Harper Torchbooks.

Clausing K.A. (2015) The Effect of Profit Shifting on the Corporate Tax Base in the United States and Beyond. Working Paper, Reed College Department of Economics. Available at: https://papers.ssrn.com/sol3/papers. cfm?abstract_id=2685442 (accessed 28 December 2018).

Cockfield A.J. (2006) The Rise of the OECD As Informal 'World Tax Organization' Through National Responses to E-Commerce Tax Challenges. Yale Journal of Law and Technology, vol. 8, no 1, pp. 136-87.

Cooper A.F., Pouliot V. (2015) How Much Is Global Governance Changing? The G20 as International Practice. Cooperation and Conflict, vol. 50, no 3, pp. 334-450.

Cooper A., Thakur R. (2013) The Group of 20 (G20). New York: Routledge.

Cox R.C. (1986) Social Forces, States, and World Orders: Beyond International Relations Theory. Neorealism and its Critics (R.O. Keohane (ed.)). New York: Columbia University Press, pp. 204-254.

Dagan T. (2018) International Tax Policy: Between Competition and Cooperation. Cambridge: Cambridge University Press.

Devereux M.P., Griffith R., Klemm A. (2002) Corporate Income Tax Reforms and International Competition. Economic Policy, vol. 17, no 35, pp. 449-95.

Dietsch P., Rixen T. (eds) (2016) Global Tax Governance: What Is Wrong and How to Fix It. Colchester: ECPR Press.

Doud R., Graetz M.J. (2013) Technological Innovation, International Competition, and the Challenges of International Income Tax. Columbia Law Review, vol. 113, no 2, pp. 347-445.

Eccleston R. (2012) The Dynamics of Global Economic Governance: The Financial Crisis, the OECD and the Politics of International Tax Cooperation. Cheltenham: Edward Elgar.

Economic and Financial Commission (1923) Report on Double Taxation Submitted to the Financial Committee - Economic and Financial Commission by the Experts on Double Taxation, League of Nations Doc. E.F.S.73.F.19. Available at: http://adc.library.usyd.edu.au/view?docId=split/law/xml-main-texts/brulegisource-bibl-1.xml;collection $=;$ database $=;$ query $=$;brand $=$ default $($ accessed 29 December 2018).

Edwards J., Keen M. (1996) Tax Competition and Leviathan. European Economic Review, vol. 40, pp. 113-34.

Group of 20 (G20) (2018a) Digital Economy Ministerial Declaration. Available at: http://www.g20.utoronto. ca/2018/2018-08-24-digital.html (accessed 2 January 2019).

Group of 20 (G20) (2018b) Leaders' Declaration: Building Consensus for Fair and Sustainable Development. Available at: http://www.g20.utoronto.ca/2018/2018-leaders-declaration.html (accessed 1 December 2018). 
Graetz M.J. (2015) Can 20th Century Business Income Tax Regime Serve a 21st Century Economy? Australian Tax Foundation, vol. 30, pp. 551-67.

Graetz M.J. (2016) Follow the Money: Essays in International Taxation. New Haven: Yale Law School Press.

Grinberg I. (2015) Breaking BEPS: The New International Tax Diplomacy. Georgetown Law Journal, vol. 104, pp. 1787-1821.

Guvenen F., Mataloni Jr., R.J., Rassier D.G., Ruhl K.J. (2017) Offshore Profit Shifting and Domestic Productivity Measurement. Working Paper 23324, National Bureau of Economic Research. Available at: http://www. nber.org/papers/w23324 (accessed 28 December 2018).

Haas P. (1992) Introduction: Epistemic Communities and International Policy Coordination. International Organization, vol. 46, no 1, pp. 1-35.

Hajnal P.I. (2014) The G20: Evolution, Interrelationships, Documentation. Dorchester: Ashgate.

Heath J. (2014. Morality, Competition, and the Firm: The Market Failures Approach. Oxford: Oxford University Press.

Hymer S. (1970) The Efficiency (Contradictions) of Multinational Corporations. The American Economic Review, vol. 60, no 2, pp. 441-8.

Keen M. (1992) The Welfare Economics of Tax Co-Ordination in the European Community: A Survey. Fiscal Studies, vol. 14, no 2, pp. 15-36.

Keen M., Wildasin D. (2004) Pareto Efficient International Taxation. The American Economics Review, vol. 94 , no 1, pp. 259-75.

Kemmerling A. (2011) From Convergence to Diffusion: The EU's Influence on National Tax Systems. ACES Cases, No 2011.2, American Consortium on European Union Studies.

Kemmerling A., Seils E. (2009) The Regulation of Redistribution: Managing Conflict in Corporate Tax Competition. West European Politics, vol. 32, no 4, pp. 756-73.

Keohane R., Nye J. (1977) Power and Interdependence. Boston: Little Brown and Company.

Keohane R. (1984) After Hegemony: Cooperation and Discord in the World Political Economy. Princeton: Princeton University Press.

Kerzner D.S., Chodikoff D.W. (2016) International Tax Evasion in the Global Information Age. Basingstoke: Palgrave MacMillan.

Kirton J.J. (1989) Contemporary Concert Diplomacy: The Seven-Power Summit and the Management of International Order. Paper presented at the annual convention of the International Studies Association, 29 March - 1 April, London. Available at: www.g8.utoronto.ca/scholar/kirton198901 (accessed 18 December 2018).

Kirton J.J. (1993) The Seven Power Summits as a New Security Institution. Building a New Global Order: Emerging Trends in International Security (D. Dewitt, D. Haglund, J.J. Kirton (eds)). Oxford: Oxford University Press.

Kirton J.J. (1999) Economic Cooperation: Summitry, Institutions, and Structural Change. Structural Change and Cooperation in the Global Economy (G. Boyd, J.H. Dunning (eds)). Cheltenham: Edward Elgar.

Kirton J.J. (2000) The Dynamics of G7 Leadership in Crisis Response and System Reconstruction. New Directions in Global Economic Governance: Managing Globalization in the Twenty First Century (J.J. Kirton, G.M. von Furstenberg (eds)). Aldershot: Ashgate.

Kirton J.J. (2013a) G20 Governance for a Globalized World. Surrey: Ashgate.

Kirton JJ. (2013b) The System Hub Model of G20 Governance. International Organisations Research Journal, vol. 8, no 3, pp. 5-30.

Kirton J.J. (2015) Advancing G8 and G20 Effectiveness Through Improved Accountability Assessment. The G8-G20 Relationship in Global Governance (J.J. Kirton, M. Larionova (eds)). Aldershot: Ashgate.

Kirton J.J. (2019) Advancing Global Openness: G7 Governance of Globalization. The G7, Anti-Globalism and the Governance of Globalization (C. Oldani, J. Wouters (eds)). London: Routledge. 
Kirton J.J., Kulik J. (2012a) The Shortcomings of the G20 Los Cabos Summit. Toronto: G20 Research Group, 27 June. Available at: www.g20.utoronto.ca/analysis/120627-kirton-kulik-shortcomings.html (accessed 18 December 2018).

Kirton J.J., Kulik J. (2012b) A Summit of Significant Success: G20 Los Cabos Leaders Deliver the Desired Double Dividend. Los Cabos: G20 Research Group, 19 June. Available at: www.g20.utoronto.ca/analysis/120619kirton-success.html (accessed 18 December 2018).

Kirton J.J., Warren B. (2018) G20 Governance of Digitization. International Organisations Research Journal, vol. 13, no 2, pp. 16-41.

Krasner S.D. (1983) International Regimes. Ithaca: Cornell University Press.

Krasner S.D. (1976) State Power and the Structure of International Trade. World Politics, vol. 28, no 3, pp. 317-47.

Kuttner R. (2016) Can Democracy Survive Global Capitalism? New York: W.W. Norton.

Latulippe L. (2016) Tax Competition: An Internalized Policy Goal. Global Tax Governance: What Is Wrong and How to Fix It (P. Dietsch, R. Rixen (eds)). Colchester: ECPR Press.

Larionova M.V., Rakhmangulov M.R., Shelepov A. (2015a) Assessing G7/8 and G20 Effectiveness in Global Governance. The G8-G20 Relationship in Global Governance (J.J. Kirton, M. Larionova (eds)). Aldershot: Ashgate.

Larionova M.V., Rakhmangulov M.R., Sakharov A.G., Shelepov A.V. (2015b) B20-G20 Engagement: Achievements and Challenges. The G8-G20 Relationship in Global Governance (J. J. Kirton, M. Larionova (eds)). Aldershot: Ashgate.

Li J. (2017) Triple Non-Taxation and BEPS: Implications. A Global Analysis of Tax Treaty Disputes (E. Baistrocchi (ed.)). Cambridge.

Li J., Cockfield A., Wilkie J.S. (2014) International Taxation in Canada 3rd edition. Toronto: LexisNexis.

Mendoza E.G., Tesar L.L. (1998) The International Ramifications of Tax Reforms: Supply-Side Economics in a Global Economy. The American Economic Review, vol. 88, no 1, pp. 226-45.

Milanovic B. (2016) Global Inequality: A New Approach for the Age of Globalization. Cambridge: The Belknap Press of Harvard University.

Motala M.F. (2016a) Book Note: Global Tax Governance: What Is Wrong and How to Fix It. Canadian Tax Journal, vol. 64, no 3, pp. 694-8.

Motala M.F. (2016b) Fixing Our Broken International Tax Regime. Canadian Bar Association National. Available at: http://www.nationalmagazine.ca/Blog/April-2016/Fixing-our-broken-international-tax-regime.aspx (accessed 18 December 2018).

Motala M.F. (2016c) The Taxi-Cab Problem Revisited: Law and Ubernomics in the Sharing Economy. Banking and Finance Law Review, vol. 33, no 2, pp. 467-511.

Motala M.F. (2018a) G20 Performance on International Taxation. Argentina: The Buenos Aires Summit (J.J. Kirton (ed.)). London: GT Media Group Ltd.

Motala M. F. (2018b) The New Global Politics of Sovereign International Tax: Space, Time and Why BEPS Is Not the Final Frontier. Banking and Finance Law Review, vol. 33, no 3, pp. 365-413.

Organisation for Economic Co-operation and Development (OECD) (1960) Convention on the Organisation for Economic Co-operation and Development, 1960, as read 14 December, 1960. Available at: http://www.oecd.org/ general/conventionontheorganisationforeconomicco-operationanddevelopment.htm (accessed 18 December 2018).

Organisation for Economic Co-operation and Development (OECD) (1998) Electronic Commerce: Taxation Framework Conditions. Available at: https://www.oecd.org/ctp/consumption/1923256.pdf (accessed 1 January 2019).

Organisation for Economic Co-operation and Development (OECD) (2002) Agreement on Exchange of Information on Tax Matters. Available at: http://www.oecd.org/ctp/exchange-of-tax-information/2082215.pdf (accessed 1 November 2018). 
Organisation for Economic Co-operation and Development (OECD) (2015) Measuring and Monitoring BEPS: Action 11 Final Report. Paris: OECD.

Organisation for Economic Co-operation and Development (OECD) (2017) Model Tax Convention on Income and Capital, as read on 21 November 2017. Available at: https://read.oecd-ilibrary.org/taxation/modeltax-convention-on-income-and-on-capital-condensed-version-2017_mtc_cond-2017-en (accessed 28 December 2018).

Organisation for Economic Co-operation and Development (OECD) (2018a) BEPS Action 5 Peer Review and Monitoring. Available at: http://www.oecd.org/tax/beps/beps-action-5-peer-review-and-monitoring.htm (accessed 1 November 2018).

Organisation for Economic Co-operation and Development (OECD) (2018b) BEPS Action 14 Peer Review and Monitoring. Available at: http://www.oecd.org/tax/beps/beps-action-14-peer-review-and-monitoring. htm (accessed 1 November 2018).

Organisation for Economic Co-operation and Development (OECD) (2018c) Country-By-Country Reporting. Available at: http://www.oecd.org/tax/beps/country-by-country-reporting.htm (accessed 1 November 2018).

Organisation for Economic Co-operation and Development (OECD) (2018d) OECD Releases Peer Review Document for Assessment of the BEPS Action 6 Minimum Standard. Available at: http://www.oecd.org/tax/ beps/oecd-releases-peer-review-document-for-assessment-beps-action-6-minimum-standard.htm (accessed 1 November 2018).

Organisation for Economic Co-operation and Development (OECD) (2018e) Tax Challenges Arising from Digitalisation: Interim Report 2018. Paris: OECD. Available at: https://www.oecd-ilibrary.org/ docserver/9789264293083-en.pdf?expires $=1546016844 \& \mathrm{id}=\mathrm{id} \&$ accname $=$ guest $\&$ checksum $=3 \mathrm{C} 5733596 \mathrm{DD}$ F5E3FD570CCE4375FC9AA (accessed 20 December 2018).

Piketty T. (2013) Capital in the 21st Century. Cambridge: Harvard University Press.

Piketty T., Saez E. (2012) A Theory of Optimal Capital Allocation. NBER Working Paper 17989, National Bureau of Economic Research.

Piketty T., Saez E., Stantcheva S. (2011) Optimal Taxation of Top Labour Incomes: A Tale of Three Elasticities. CEPR Discussion Paper 17616. Available at: https://www.nber.org/papers/w17616.pdf (accessed 22 April 2019).

Piketty T., Saez E. (2004) Income Inequality in the United States, 1913-2002. Department of Economics Working Paper, University of California, Berkeley.

Reus-Smit C. (2001) The Strange Death of Liberal International Relations Theory. European Journal of International Law, vol. 12, no 3, pp. 573-93.

Rixen T. (2011) From Double Tax Avoidance to Tax Competition: Explaining the Institutional Trajectory of International Tax Governance. Review of International Political Economy, vol. 18, no 2, pp. 1-31.

Ruggie J.G. (1982) International Regimes, Transactions, and Change: Embedded Liberalism in the Postwar Economic Order. International Organization, vol. 36, no 2, pp. 379-415.

Schmidt V.A. (2008) Discursive Institutionalism: The Explanatory Power of Ideas and Discourse. Annual Review of Political Science, vol. 11, no 1, pp. 303-26.

Sharman J.C. (2012) Seeing Like the OECD on Tax. New Political Economy, vol. 17, no 1, pp. 17-33.

Simmons B.A. (2001) The International Politics of Harmonization: The Case of Capital Market Regulation. International Organization, vol. 55, no 3, pp. 589-620. Available at: https://www.cambridge.org/core/journals/ international-organization/article/international-politics-of-harmonization-the-case-of-capital-market-regul ation/62E1075E3CC31A636DEF25FB696E654E (accessed 1 December 2018).

Srnicek N. (2017) Platform Capitalism. Cambridge: Polity Press.

Tørsløv T., Wier L., Zucman G. (2018) The Missing Profits of Nations, VOX CEPR Public Policy, 23 July. Available at: https://voxeu.org/article/missing-profits-nations (accessed 2 January 2019). 
Treaty of Westphalia, Peace Treaty between the Holy Roman Emperor and the King of France and Their Respective Allies, entered into force. 24 October 1648. Available at: http://avalon.law.yale.edu/17th_century/westphal.asp (accessed 29 December 2018).

UK Public Accounts Committee (2012) Tax Avoidance by Multinational Companies. London: UK Parliament. Available at: https://publications.parliament.uk/pa/cm201213/cmselect/cmpubacc/716/71605.htm> (accessed 1 August 2018).

Waltz K. (1979) Theory of International Politics. Reading: Addison Wesley Publishing Company.

Wendt A. (1998) On Constitution and Causation in International Relations. Review of International Studies, vol. 24, no 5, pp. 101-17.

Wier L., Reynolds H. (2018) Big and 'Unprofitable:' How 10\% of Multinational Firms Do 98\% of Profit-Shifting. United Nations University UNU-WIDER Working Paper 2018/111. Available at: http://sa-tied.wider.unu. edu/article/big-and-unprofitable-how-10-multinational-firms-do-98-profit-shifting (accessed 20 December 2018).

Wilson J.D. (1986) A Theory of Interregional Tax Competition. Journal of Urban Economics, vol. 19, pp. $296-$ 315 .

Woodward R. (2016) A Strange Revolution: Mock Compliance and the Failure of the OECD's International Tax Transparency Regime. Global Tax Governance: What is Wrong and How to Fix It (P. Dietsch, T. Rixen (eds)). London: ECPR Press.

Zodrow G.R., Mieszkowski P. (1986) Pigou, Tiebout, Property Taxation, and the Underprovision of Local Public Goods. Journal of Urban Economics, vol. 39, no 3, pp. 312-16.

Zucman G. (2014) Taxing Across Borders: Tracking Personal Wealth and Corporate Profits. Journal of Economic Perspectives, vol. 28, no 4, pp. 121-48.

Zucmann G. (2015) The Hidden Wealth of Nations: The Scourge of Tax Havens. Chicago: Chicago University Press. 


\title{
Вклад «Группы двадцати» и ОЭСР в новое глобальное управление в сфере налогообложения 1
}

\author{
М.Ф. Мотала
}

Мотала Майкл Ф. - исследователь Исследовательского центра «Группы двадцати»; стипендиат имени Жозефа-Армана Бомбардье (Канадский Совет по научным исследованиям в сфере социальных и гуманитарных наук); стипендиат имени Фредерика Бастиа по политической экономии (Центр Меркатуса Университета им. Джорджа Мэйсона); стипендиат по этике искусственного интеллекта (Центр этики Университета Торонто); аспирант факультета политических наук Университета Торонто; Canada, Toronto M5S 3K7 Ontario, 1 Devonshire Place, Room 209 N; E-mail: michael.motala@columbia.edu

Трансатлантические корпоративные налоговые скандалы 2012 г., связанные с Amazon, Google и Starbucks, выявили масштабы офшоринга со стороны цифровых транснациональных корпораций, поставив глобальное управление международным налоговым законодательством и политикой перед серьезными дилеммами. По оценкам ОЭСР (2015 г.), перемещение прибыли корпораций ежегодно уменьшает глобальную налоговую базу на 240 млрд долл. Существующая литература установила связи между уклонением от уплаты налогов и усилением внутреннего социально-экономического неравенства, снижением перераспределительного потенциала государств, пагубным воздействием на рост ВВП и ростом антиглобализма в форме популистского недовольства, предоставив, таким образом, бесспорные доказательства, что глобальная налоговая конкуренция наносит социальный и экономический ущерб. В ответ на протесты общественности мировые лидеры на саммите в Лос-Кабосе в 2012 г. поставили перед ОЭСР задачу бороться с размыванием национальной налоговой базы, а Инклюзивная структура по реализации инициативы по борьбе с размыванием налогооблагаемой базы и перемещением прибыли (ВЕРS) в настоящее время насчитывает 123 государства-участника, на которые приходится 95\% глобального ВВП. Хотя налогообложение лежит в основе общественного договора, новое глобальное налоговое управление недостаточно изучено теоретически и практически в доминирующей литературе по политическим наукам. Это исследование опирается на междисииплинарный подход, объединяющий право и экономику, чтобы доказать, что, хотя глобальное налоговое сотрудничество под эгидой «Группы двадиати» и ОЭСР можно считать успешным, основываясь на данных об исполнении согласованных мер первого порядка, аспекты принуждения к реализации мер в отношении BEPS недостаточно изучены как в теоретическом, так и в прикладном аспекте. Исследование вносит вклад в метатеорию нового глобального налогового управления, которая учитывает переменные времени, институциональную сферу действий и петли обратной связи в рамках глобального процесса формирования налогово-бюджетной политики, с целью стимулировать дальнейшие исследования. В заключительном разделе приводятся рекомендации по глобальной налоговой политике, дальнейшим исследованиям по тематике ВEPS и роли «двадцатки» в глобальном управлении цифровой экономикой.

Ключевые слова: глобальное управление в сфере налогообложения; международное налогообложение; налоговые отношения; международная политическая экономия

Для цитирования: Мотала М.Ф. (2019) Вклад «Группы двадцати» и ОЭСР в новое глобальное управление в сфере налогообложения // Вестник международных организаций. Т. 14. № 2. С. 52-79 (на русском и английском языках). DOI: 10.17323/1996-7845-2019-02-03.

\section{Источники}

«Группа двадцати» (2018) Декларация лидеров «Группы двадцати». Режим доступа: http://www.g20.utoronto.ca/2018/2018-leaders-declaration.html (дата обращения: 01.12.2018).

Abbott K.W., Keohane R.O., Moravcsik A., Slaughter A., Snidal D. (2000) The Concept of Legalization // International Organization. Vol. 54. No. 3. P. 401-19.

\footnotetext{
${ }^{1}$ Статья поступила в редакцию в январе 2019 г.
} 
Adler E. (1997) Seizing the Middle Ground: Constructivism in World Politics // European Journal of International Relations. Vol. 3. No. 3. P. 319-63.

Alepin B., Otis L. (2018) The Global Tax War May Already Be Under Way. The Globe and Mail, 1 January. Режим доступа: https://www.theglobeandmail.com/report-on-business/rob-commentary/the-global-taxwar-may-already-be-under-way/article37470600/ (дата обращения: 20.12.2018).

Baldwin R. (2016) The Great Convergence: Information Technology and the New Globalization. Cambridge: The Belknap Press of Harvard University.

Baldwin R., Okubo T. (2009) Tax Reform, Relocation, and Heterogenous Firms // The Scandinavian Journal of Economics. Vol. 111. No. 4. P. 741-64.

Bruner J., Raisser D.G., Ruhl K.J. (2018) Multinational Profit Shifting and Measures Throughout Economic Accounts. NBER Working Paper No 24915, National Bureau of Economic Research. Режим доступа: https:// www.nber.org/papers/w24915 (дата обращения: 28.12.2018).

Carr E.H. (1964) The Twenty Years Crisis: 1919-1939. London: Harper Torchbooks.

Clausing K.A. (2015) The Effect of Profit Shifting on the Corporate Tax Base in the United States and Beyond. Working Paper, Reed College Department of Economics. Режим доступа: https://papers.ssrn.com/sol3/papers.cfm?abstract_id=2685442 (дата обращения: 28.12.2018).

Cockfield A.J. (2006) The Rise of the OECD As Informal 'World Tax Organization' Through National Responses to E-Commerce Tax Challenges // Yale Journal of Law and Technology. Vol. 8. No. 1. P. 136-87.

Cooper A.F., Pouliot V. (2015) How Much Is Global Governance Changing? The G20 as International Practice // Cooperation and Conflict. Vol. 50. No. 3. P. 334-450.

Cooper A., Thakur R. (2013) The Group of 20 (G20). New York: Routledge.

Cox R.C. (1986) Social Forces, States, and World Orders: Beyond International Relations Theory. Neorealism and its Critics / R.O. Keohane (ed.). New York: Columbia University Press. P. 204-54.

Dagan T. (2018) International Tax Policy: Between Competition and Cooperation. Cambridge: Cambridge University Press.

Devereux M.P., Griffith R., Klemm A. (2002) Corporate Income Tax Reforms and International Competition // Economic Policy. Vol. 17. No. 35. P. 449-95.

Dietsch P., Rixen T. (eds) (2016) Global Tax Governance: What is Wrong and How to Fix It. Colchester: ECPR Press.

Doud R., Graetz M.J. (2013) Technological Innovation, International Competition, and the Challenges of International Income Tax // Columbia Law Review. Vol. 113. No. 2. P. 347-445.

Eccleston R. (2012) The Dynamics of Global Economic Governance: The Financial Crisis, the OECD and the Politics of International Tax Cooperation. Cheltenham: Edward Elgar.

Economic and Financial Commission (1923) Report on Double Taxation Submitted to the Financial Committee - Economic and Financial Commission by the Experts on Double Taxation, League of Nations Doc. E.F.S.73.F.19. Режим доступа: http://adc.library.usyd.edu.au/view?docId=split/law/xml-main-texts/brulegi-source-bibl-1.xml;collection=;database=;query=;brand=default (дата обращения: 29.12.2018).

Edwards J., Keen M. (1996) Tax Competition and Leviathan // European Economic Review. Vol. 40. P. 11334.

Group of 20 (G20) (2018) Digital Economy Ministerial Declaration. Режим доступа: http://www.g20.utoronto.ca/2018/2018-08-24-digital.html (дата обращения: 02.01.2019).

Graetz M.J. (2015) Can 20th Century Business Income Tax Regime Serve a 21st Century Economy? // Australian Tax Foundation. Vol. 30. P. 551-67.

Graetz M.J. (2016) Follow the Money: Essays in International Taxation. New Haven: Yale Law School Press.

Grinberg I. (2015) Breaking BEPS: The New International Tax Diplomacy // Georgetown Law Journal. Vol. 104. P. 1787-1821.

Guvenen F., Mataloni Jr., R.J., Rassier D.G., Ruhl K.J. (2017) Offshore Profit Shifting and Domestic Productivity Measurement. Working Paper 23324, National Bureau of Economic Research. Режим доступа: http:// www.nber.org/papers/w23324 (дата обращения: 28.12.2018). 
Haas P. (1992) Introduction: Epistemic Communities and International Policy Coordination // International Organization. Vol. 46. No. 1. P. 1-35.

Hajnal P.I. (2014) The G20: Evolution, Interrelationships, Documentation. Dorchester: Ashgate.

Heath J. (2014) Morality, Competition, and the Firm: The Market Failures Approach. Oxford: Oxford University Press.

Hymer S. (1970) The Efficiency (Contradictions) of Multinational Corporations // The American Economic Review. Vol. 60. No. 2. P. 441-8.

Keen M. (1992) The Welfare Economics of Tax Co-Ordination in the European Community: A Survey // Fiscal Studies. Vol. 14. No. 2. P. 15-36.

Keen M., Wildasin D. (2004) Pareto Efficient International Taxation // The American Economics Review. Vol. 94. No. 1. P. 259-75.

Kemmerling A. (2011) From Convergence to Diffusion: The EU's Influence on National Tax Systems. ACES Cases, No 2011.2, American Consortium on European Union Studies.

Kemmerling A., Seils E. (2009) The Regulation of Redistribution: Managing Conflict in Corporate Tax Competition // West European Politics. Vol. 32. No. 4. P. 756-73.

Keohane R., Nye J. (1977) Power and Interdependence. Boston: Little Brown and Company.

Keohane R. (1984) After Hegemony: Cooperation and Discord in the World Political Economy. Princeton: Princeton University Press.

Kerzner D.S., Chodikoff D.W. (2016) International Tax Evasion in the Global Information Age. Basingstoke: Palgrave MacMillan.

Kirton J.J. (1989) Contemporary Concert Diplomacy: The Seven-Power Summit and the Management of International Order. Paper presented at the annual convention of the International Studies Association, 29 March - 1 April, London. Режим доступа: www.g8.utoronto.ca/scholar/kirton198901 (дата обращения: 18.12.2018).

Kirton J.J. (1993) The Seven Power Summits as a New Security Institution. Building a New Global Order: Emerging Trends in International Security / D. Dewitt, D. Haglund, J. J. Kirton (eds). Oxford: Oxford University Press.

Kirton J.J. (1999) Economic Cooperation: Summitry, Institutions, and Structural Change. Structural Change and Cooperation in the Global Economy / G. Boyd, J. H. Dunning (eds). Cheltenham: Edward Elgar.

Kirton J.J. (2000) The Dynamics of G7 Leadership in Crisis Response and System Reconstruction. New Directions in Global Economic Governance: Managing Globalization in the Twenty First Century / J.J. Kirton, G.M. von Furstenberg (eds). Aldershot: Ashgate. P. 59-94.

Kirton J.J. (2013a) G20 Governance for a Globalized World. Surrey: Ashgate.

Kirton J.J. (2013b) The System Hub Model of G20 Governance // International Organisations Research Journal. Vol. 8. No. 3. P. 5-30.

Kirton J.J. (2015) Advancing G8 and G20 Effectiveness Through Improved Accountability Assessment. The G8-G20 Relationship in Global Governance / J.J. Kirton, M. Larionova (eds). Aldershot: Ashgate. P. 241-51.

Kirton J.J. (2019) Advancing Global Openness: G7 Governance of Globalization. The G7, Anti-Globalism and the Governance of Globalization / C. Oldani, J. Wouters (eds). London: Routledge.

Kirton J.J., Kulik J. (2012a) The Shortcomings of the G20 Los Cabos Summit. Toronto: G20 Research Group. 27 June. Режим доступа: www.g20.utoronto.ca/analysis/120627-kirton-kulik-shortcomings.html (дата обращения: 18.12.2018).

Kirton J.J., Kulik J. (2012b) A Summit of Significant Success: G20 Los Cabos Leaders Deliver the Desired Double Dividend. Los Cabos: G20 Research Group. 19 June. Режим доступа: www.g20.utoronto.ca/ analysis/120619-kirton-success.html (дата обращения: 18.12.2018).

Kirton J.J., Warren B. (2018) G20 Governance of Digitization // International Organisations Research Journal. Vol. 13. No. 2. P. 16-41.

Krasner S.D. (1983) International Regimes. Ithaca: Cornell University Press. 
Krasner S.D. (1976) State Power and the Structure of International Trade // World Politics. Vol. 28. No. 3. P. 317-47.

Kuttner R. (2016) Can Democracy Survive Global Capitalism? New York: W.W. Norton.

Latulippe L. (2016) Tax Competition: An Internalized Policy Goal. Global Tax Governance: What is Wrong and How to Fix It / P. Dietsch, R. Rixen (eds). Colchester: ECPR Press.

Larionova M.V., Rakhmangulov M.R., Shelepov A. (2015a) Assessing G7/8 and G20 Effectiveness in Global Governance. The G8-G20 Relationship in Global Governance / J.J. Kirton, M. Larionova (eds). Aldershot: Ashgate. P. 77-107.

Larionova M.V., Rakhmangulov M.R., Sakharov A.G., Shelepov A.V. (2015b) B20-G20 Engagement: Achievements and Challenges. The G8-G20 Relationship in Global Governance / J.J. Kirton, M. Larionova (eds). Aldershot: Ashgate. P. 134-71.

Li J. (2017) Triple Non-Taxation and BEPS: Implications. A Global Analysis of Tax Treaty Disputes / E. Baistrocchi (ed.). Cambridge. P. 1497-1511.

Li J., Cockfield A., Wilkie J.S. (2014) International Taxation in Canada 3rd edition. Toronto: LexisNexis.

Mendoza E.G., Tesar L.L. (1998) The International Ramifications of Tax Reforms: Supply-Side Economics in a Global Economy // The American Economic Review. Vol. 88. No. 1. P. 226-45.

Milanovic B. (2016) Global Inequality: A New Approach for the Age of Globalization. Cambridge: The Belknap Press of Harvard University.

Motala M.F. (2016a) Book Note: Global Tax Governance: What Is Wrong and How to Fix It // Canadian Tax Journal. Vol. 64. No. 3. P. 694-8.

Motala M.F. (2016b) Fixing Our Broken International Tax Regime // Canadian Bar Association National. Режим доступа: http://www.nationalmagazine.ca/Blog/April-2016/Fixing-our-broken-international-taxregime.aspx (дата обращения: 18.12.2018).

Motala M.F. (2016c) The Taxi-Cab Problem Revisited: Law and Ubernomics in the Sharing Economy // Banking and Finance Law Review. Vol. 33. No. 2. P. 467-511.

Motala M.F. (2018a) G20 Performance on International Taxation. Argentina: The Buenos Aires Summit / J.J. Kirton (ed.). London: GT Media Group Ltd. P. 114-5.

Motala M.F. (2018b) The New Global Politics of Sovereign International Tax: Space, Time and Why BEPS Is Not the Final Frontier // Banking and Finance Law Review. Vol. 33. No. 3. P. 365-413.

Organisation for Economic Co-operation and Development (OECD) (1960) Convention on the Organisation for Economic Co-operation and Development. Режим доступа: http://www.oecd.org/general/conventionontheorganisationforeconomicco-operationanddevelopment.htm (дата обращения: 18.12.2018).

Organisation for Economic Co-operation and Development (OECD) (1998) Electronic Commerce: Taxation Framework Conditions. Режим доступа: https://www.oecd.org/ctp/consumption/1923256.pdf (дата обращения: 01.01.2019).

Organisation for Economic Co-operation and Development (OECD) (2002) Agreement on Exchange of Information on Tax Matters. Режим доступа: http://www.oecd.org/ctp/exchange-of-tax-information/2082215. pdf (дата обращения: 01.11.2018).

Organisation for Economic Co-operation and Development (OECD) (2015) Measuring and Monitoring BEPS: Action 11 Final Report. Paris: OECD.

Organisation for Economic Co-operation and Development (OECD) (2017) Model Tax Convention on Income and Capital, as read on 21 November. Режим доступа: https://read.oecd-ilibrary.org/taxation/modeltax-convention-on-income-and-on-capital-condensed-version-2017_mtc_cond-2017-en (дата обращения: 28.12.2018).

Organisation for Economic Co-operation and Development (OECD) (2018a) BEPS Action 5 Peer Review and Monitoring. Режим доступа: http://www.oecd.org/tax/beps/beps-action-5-peer-review-and-monitoring. htm (дата обращения: 01.11.2018).

Organisation for Economic Co-operation and Development (OECD) (2018b) BEPS Action 14 Peer Review and Monitoring. Режим доступа: http://www.oecd.org/tax/beps/beps-action-14-peer-review-and-monitoring.htm (дата обращения: 01.11.2018). 
Organisation for Economic Co-operation and Development (OECD) (2018c) Country-By-Country Reporting. Режим доступа: http://www.oecd.org/tax/beps/country-by-country-reporting.htm (дата обращения: 01.11.2018).

Organisation for Economic Co-operation and Development (OECD) (2018d) OECD Releases Peer Review Document for Assessment of the BEPS Action 6 Minimum Standard. Режим доступа: http://www.oecd.org/ tax/beps/oecd-releases-peer-review-document-for-assessment-beps-action-6-minimum-standard.htm (дата обращения: 01.11.2018).

Organisation for Economic Co-operation and Development (OECD) (2018e) Tax Challenges Arising from Digitalisation: Interim Report 2018. Paris: OECD. Режим доступа: https://www.oecd-ilibrary.org/ docserver/9789264293083-en.pdf? expires $=1546016844 \& \mathrm{id}=\mathrm{id} \&$ accname $=$ guest $\&$ checksum=3C5733596DD F5E3FD570CCE4375FC9AA (дата обращения: 20.12.2018).

Piketty T. (2013) Capital in the 21st Century. Cambridge: Harvard University Press.

Piketty T., Saez E. (2012) A Theory of Optimal Capital Allocation. NBER Working Paper 17989, National Bureau of Economic Research.

Piketty T., Saez E., Stantcheva S. (2011) Optimal Taxation of Top Labour Incomes: A Tale of Three Elasticities. CEPR Discussion Paper 17616. Режим доступа: https://www.nber.org/papers/w17616.pdf (дата обращения: 22.04.2019).

Piketty T., Saez E. (2004) Income Inequality in the United States, 1913-2002. Department of Economics Working Paper, University of California, Berkeley.

UK Public Accounts Committee (2012) Tax Avoidance By Multinational Companies. London: UK Parliament. Режим доступа: https://publications.parliament.uk/pa/cm201213/cmselect/cmpubacc/716/71605.htm (дата обращения: 01.08.2018).

Reus-Smit C. (2001) The Strange Death of Liberal International Relations Theory // European Journal of International Law. Vol. 12. No. 3. P. 573-93.

Rixen T. (2011) From Double Tax Avoidance to Tax Competition: Explaining the Institutional Trajectory of International Tax Governance // Review of International Political Economy. Vol. 18. No. 2. P. 1-31.

Ruggie J.G. (1982) International Regimes, Transactions, and Change: Embedded Liberalism in the Postwar Economic Order // International Organization. Vol. 36. No. 2. P. 379-415.

Schmidt V.A. (2008) Discursive Institutionalism: The Explanatory Power of Ideas and Discourse // Annual Review of Political Science. Vol. 11. No. 1. P. 303-26.

Sharman J.C. (2012) Seeing Like the OECD on Tax // New Political Economy. Vol. 17. No. 1. P. 17-33.

Simmons B.A. (2001) The International Politics of Harmonization: The Case of Capital Market Regulation // International Organization. Vol. 55. No. 3. Р. 589-620. Режим доступа: https://www.cambridge.org/core/ journals/international-organization/article/international-politics-of-harmonization-the-case-of-capitalmarket-regulation/62E1075E3CC31A636DEF25FB696E654E (дата обращения: 01.12.2018).

Srnicek N. (2017) Platform Capitalism. Cambridge: Polity Press.

Tørsløv T., Wier L., Zucman G. (2018) The Missing Profits of Nations // VOX CEPR Public Policy. 23 July. Режим доступа: https://voxeu.org/article/missing-profits-nations (дата обращения: 02.01.2019).

Treaty of Westphalia (1648) Peace Treaty between the Holy Roman Emperor and the King of France and Their Respective Allies. Режим доступа: http://avalon.law.yale.edu/17th_century/westphal.asp (дата обращения: 29.12.2018).

Waltz K. (1979) Theory of International Politics. Reading: Addison Wesley Publishing Company.

Wendt A. (1998) On Constitution and Causation in International Relations // Review of International Studies. Vol. 24. No. 5. P. 101-17.

Wier L., Reynolds H. (2018) Big and 'Unprofitable:' How 10\% of Multinational Firms Do 98\% of Profit-Shifting. United Nations University UNU-WIDER Working Paper 2018/111. Режим доступа: http://sa-tied.wider. unu.edu/article/big-and-unprofitable-how-10-multinational-firms-do-98-profit-shifting (дата обращения: 20.12.2018).

Wilson J.D. (1986) A Theory of Interregional Tax Competition // Journal of Urban Economics. Vol. 19. P. 296-315. 
Woodward R. (2016) A Strange Revolution: Mock Compliance and the Failure of the OECD's International Tax Transparency Regime. Global Tax Governance: What is Wrong and How to Fix It / P. Dietsch, T. Rixen (eds). London: ECPR Press.

Zodrow G.R., Mieszkowski P. (1986) Pigou, Tiebout, Property Taxation, and the Underprovision of Local Public Goods // Journal of Urban Economics. Vol. 39. No. 3. P. 312-16.

Zucman G. (2014) Taxing Across Borders: Tracking Personal Wealth and Corporate Profits // Journal of Economic Perspectives. Vol. 28. No. 4. P. 121-48.

Zucmann G. (2015) The Hidden Wealth of Nations: The Scourge of Tax Havens. Chicago: Chicago University Press. 